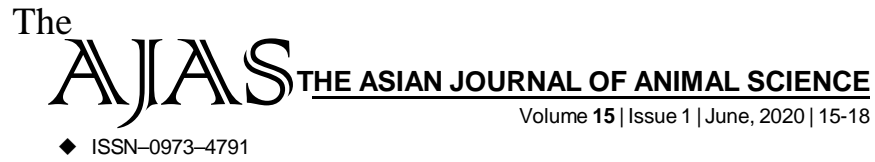

DOI : 10.15740/HAS/TAJAS/15.1/15-18 Visit us | www.researchjournal.co.in $\mathrm{S}^{\mathrm{S}}$

RESEARCH ARTICLE

\title{
Comparative study of traditional feed and supplement feed with Azolla on milk yield in cows under tribal belt of Dhar district of MP
}

J. S. Rajpoot, K. S. Kirad, S. S. Chauhan and G. S. Gathiye

Author for Corresponding -

\section{K. S. Kirad}

Krishi Vigyan Kendra, Dhar

(M.P.) India

Email:kskal24@rediffmail.com

\begin{abstract}
There in an acute shortage of feed and fodder for dairy animals due to lack of land availability for growing fodder for animals and high population density. In India majority of farmers are small and marginal land holders. By the use of concentrate feed cost of milk production is increased. The low milk yield in the milch animals under tribal belt due to nutritional deficiency in lacking of green fodder and concentrates. Azolla is a wonderful floating fern rich in protein, amino acids, vitamins and minerals. On farm trials (OFT) were conducted at farmers field during 2016-17 to 2018-19 for assessment of the Azolla cultivation technology and its impact on milk yield introduced by RVSKVV, Krishi Vigyan Kendra, Dhar (M.P.) under tribal belt. The control group representing farmers practice was fed wheat straw and green fodder with wheat bran. In the treatment group $1.5 \mathrm{~kg}$ fresh Azolla per animal per day was supplemented over conventional ration. The average daily milk yield was significantly higher in treatment group. Success of this technology led to wide scale adoption by the tribal farmers of Dhar district and KVK Dhar has so far established 940 Azolla cultivation units during the last five years in the district.
\end{abstract}

KEY WORDS....... Azolla, OFT, Milk yield

HOW TO CITE THIS ARTICLE - Rajpoot, J.S., Kirad, K.S., Chauhan, S.S. and Gathiye, G.S. (2020). Comparative study of traditional feed and supplement feed with Azolla on milk yield in cows under tribal belt of Dhar district of MP. Asian J. Animal Sci., 15(1): 15-18.DOI:10.15740/HAS/TAJAS/ 15.1/15-18.Copyright@2020:HindAgri-Horticultural Society.

ARTICLE CHRONICLE - Received : 04.04.2020; Revised : 05.05.2020; Accepted : 21.05.2020 